\title{
THE GOOD LIFE AND THE IDEAL OF FLEXIBILITY
}

\author{
BLANKA ŠULAVÍKOVÁ
}

\begin{abstract}
The author focuses on the issue of the "good life" in relation to a strong ideal of flexibility that operates in contemporary western culture. The era we live in may be called a "continuous stream of innovations" and can be characterized by a fundamental requirement "to adapt flexibly and cope with the new". The need for such flexibility is mentally and physically demanding; the demands also mark the approach to values, the ideas of the good life and the project of the paths in life. Contemporary people in western civilization are exposed to the pressure of modern culture that has caused problems in the past decades as a result of the incompatibility of its fragmentary value systems. People today apply their abilities in a never-ending whirl of activities and effort where there is no more space available for becoming aware of and for perceiving the deeper meaning of and formulating their specific ideal of the good life.
\end{abstract}

Keywords: good life; humanistic psychology; authenticity; flexibility; integrity.

\section{Introduction}

We live in a period that may be called "a continuous stream of innovations" and which can be characterized by a central requirement "to adapt flexibly and cope with the new". The French sociologist G. Lipovetsky has argued that in the era of excessive competitiveness a new magic formula for human mobilization dominates and a passion for innovation is emerging. The moral obligation of self-improvement has been replaced by a new entrepreneurial demand for innovation and flexibility. The internally stable individual has been replaced by a flexible person able to adapt to a particular situation and to current needs (Lipovetsky 1999, 142). Such flexibility is physically and mentally demanding; these demands leave their mark on the attitudes people have regarding values, ideas of the good life and the projects encountered on the path of life. To adapt flexibly in time and space implies not having strong ties to a particular place, not being bound by customs and not being tied to a steady lifestyle.

\section{Flexibility}

A strong ideal of flexibility plays a decisive part in the fact that the period in human life that was previously regarded as a time of immaturity and as something that should be overcome as soon as possible has now developed into a long-term and desired state. It seems to be advantageous if a person has no consistent project in his or her life or a value system with fixed priorities. Opinion inconsistency also appears to be an advantage manifested as a 'flexible spiritual condition', which means not having opinions, but simply ideas. Sociologists and psychologists maintain that the only value professed in the past decades by a high percentage 
of young people in western and post-communist countries is plurality. To declare one's support for strong beliefs is out of fashion. What was once valued as part of a "steady character" for those who struggled to excel and achieve success is today a collection of useless requisites and restrictions. What E. H. Erikson once called an adolescent "crisis of identity" now appears to be a satisfactory status: therefore, young people do not see growing up as advantageous and they are in no hurry to mature. The need for flexible adaptability is expressed by two trends: on the one hand it produces ambitious individuals who evaluate the good life in terms of success, regardless of the way in which it is achieved and to what sphere it is related. On the other hand, it produces those who do not want to or who are not able to formulate their own idea on they type of life they should lead (for more details, see Šulavíková 2006a).

Modern society deepens the fragmentalization of human self-realization with regard to the atomization of human activities and this leads to problems with their integration into the continuum of life experience. In this respect, many authors have noted future changes in shaping personal identity that assume the possibility of and ability for self-reflection focused on the synthesis of the self. The question of whether there is an unproblematic connection between the psychological and social aspects of identity and the concept of values, primarily the values a person has and the good life, has gradually developed into an issue. The question that has become more disputable is whether the assumption of the identity, continuity and coherence of an individual is sustainable in a situation of value plurality (Sisáková 2001, 14). For instance, according to the French philosopher, Ricouer, the essence of humanity is bound up with personal identity, which relies both on the fact that a person differs from other people, and on the continuity of the personality, where the characteristic features are independent of time and life circumstances (Ricouer 1993, 4-6). On the other hand, the sociologist Z. Bauman refers to its absence. He believes that with postmodernity came the end of the personality pattern that would clarify all human acts (Bauman 1995, 39). The qualities that achieve success in life are different from those that were in existence earlier: consequentiality in behaviour, the continual pursuit of a chosen goal but also the elasticity of interests, the speed of change, flexible adaptation, the ability to forget that which can no longer be used. The vaguer the definition of identity, the better it is for the one whose identity it is. The truly postmodern personality is characterized by the absence of identity (ibid., 35). Furthermore, other authors agree that postmodern identity is pluralistic or constantly changing-flexible.

The people of today face a challenge presented by the ideal of flexibility: not only the necessity of "being flexible" but also of creating an impression by taking continual care of one's young and healthy appearance. This challenge is widely supported by different kinds of industries-the cosmetic, sport and media industries that participate in both its implementation and its shaping. An innovative healthy appearance is more important today than the spiritual values once so highly esteemed. The ideal of beauty has also been transferred to this area: the American neopragmatist R. Shusterman claims that the people idolized today are not men of courage and women of virtue but those who are labelled as "beautiful people" (Shusterman 2003, 372). Lipovetsky writes about the current "hygiene fever" and warns us that in earlier times, the purity of the body was a sign of moral purity, whereas today this has been replaced by an egocentric cult emphasizing health, youth and the bodily aesthetic. The body has never been the subject of such concentrated interest and of such attempts to protect and refine it. Self-esteem is no longer emphasized; it is the model of the young and seductive body that is highlighted and that is strengthening narcissistic anxiety (Lipovetsky 1999, 116-117). I. Buraj reminds us that while people were obsessed with the face for a long time, now the focus is on the body and body care. People thus succumb to the whims of fashion, to various diets and 
aesthetic surgery to achieve the perfect body (Buraj 2004, 440). With regards to the cult of the perfect body, Lipovetsky writes about the "tyranny" of beauty, a slim body, health and youth and the related discrimination of the obese, ill, and elderly. According to him, demands on youth, health, thinness, form, leisure and sex create a status of hypermobilization, stress and permanent recycling, which engenders a society of anxiety (Lipovetsky 1999).

\section{Success and Well-being}

The end of the past century witnessed a significant shift from spiritual values to material and physical ones. The current ideal of being successful is closely linked with the new cult of the body and physical beauty. The culture of hygiene and sport, aesthetics and dietetics causes individual happiness to be inextricably linked with the striving for dynamization and optimal maintenance of the self. The current ethics of happiness is not only consumerist but it is also activating and constructive in essence. Its aim is the best possible use of opportunities, eternal physical youth, not wisdom, but an assessment of physical capital (Lipovetsky 1999, 64). The ideal of being successful is associated with the cult of affluence. Lipovetsky argues that in our communities, objects and things are displayed more than moral principles; hunger for material goods wins over the obligation of humaneness, need over virtue, well-being over good. Well-being turned into God and advertising became its prophet. The dominance of consumerism and advertising in culture means that human relations are regarded as inferior to relations between humans and things. The priority of the relationship individual-thing over individual-individual, which is characteristic of modern economic ideology, has all the hallmarks of ordinary life (ibid., 64). Common culture is replete with welfare: the norm of well-being is placed above the highest ideal duties (ibid., 15).

In western culture, there is an on-going parallel struggle between the two contradictory relations to values-the culture is split: on the one hand there is all powerful money and competition fever and on the other hand, in direct contrast to those who strive to assert themselves in the sphere of the values of commercial culture and to achieve success in the world of money, there has emerged the so-called "generation X" - the generation of young people who have lost their illusions. These young people do not believe that their lives could be much better than the lives of their parents' generation. These drifting young people put off adult status for as long as possible - they study, drop out, then they travel, earn money doing temporary work all over the world, they do not establish deeper relationships, they escape from accountability to society and to themselves. They have no particular idea of their future life or the meaning of life. Such a life without values can also lead to fundamentalism and extremism of different kinds (Macek 1999).

Conservative and liberal-minded critics of contemporary culture warn of the strong emphasis laid on the ideal of being successful and the main focus on personal profits. The American moral philosopher A. MacIntyre $(2004,186)$ argues that such an approach to success is chiefly based on the possibilities of implementing one's own preferences exclusively. In liberal and conservative sociological and philosophical literature we can find critical perspectives highlighting material values as a universal trend in western culture. Freedom in contemporary society is allied with the market economy. The market economy requires people to view money and possessions as values of vital importance and to believe that they are a precondition for achieving happiness and that the "good life" equals a standard (or abovestandard) life. People expect that money to banish feelings of personal insufficiency and social disapproval, money will make them influential and will bring them respect and a life of safety and comfort. According to K. Hnilica (2005, 386), affluence and success are more important than freedom and authentic living. "Having" is more important than "being". Many research 
findings show, however, that the more people succumb to the indoctrination of material values, the less satisfied they are with their lives and the quality of their lives is also worse in other respects. Hnilica presented results that confirmed that the stronger a person's belief that happiness is dependent on material circumstance, the greater the dissatisfaction with their lives. The less neurotic and more extrovert people are, the more satisfied they are with their lives; the more people are convinced that they are not happy because they are not rich enough, the less content they are. On the other hand, indulgence in luxury and spending money had a positive impact on life satisfaction. People obsessed with money will never have enough material goods to make them happy. The more they have, the more they need to be satisfied (Hnilica 2005). ${ }^{1}$

\section{Incompatibility of Values}

The postmodern attitude to values is one of high abstraction which is not an effect of consciousness but the effect of the game. It is part of the economy which belongs to life in general and is a result of calculating the gains and losses in life (Sisáková 2001, 123-127). Along with the postmodern idea that the values of modern identity and subjectivity should be defended we find spiritual divergence, fragmentation and indifferentism. According to postmodern authors, the practice of instrumental reason introduced the ideals of success into western culture: these ideals prevent humans from understanding themselves and reflecting meaningfully upon the paths that are best for them in their lives, and what the good life might mean to them in practice. Modern subjectivity and/or individual identity and the centre of individual's authenticity are repeatedly reconstructed. The psychological and sociological aspects of identity are bound to a certain conception of values, mainly the value of the individual and the good life. However, the good life is not only associated with the demand for autonomy and authenticity but also with the horizon of the senses based on aesthetic, cognitive and ethical values through which an individual is allied with the wider social background. These interpretations are founded on the pluralist axiological standpoint—on the opinion that the values are conditioned, undergoing change and are articulated in relations. They reject the extremely monistic idea of the existence of an absolute value; the processes of evaluation are primarily bound up with the value of humanity but they insist on the objectiveness of values. The objectivity is determined by human needs and the means by which they are satisfied, both of these are formulated in culture. Humanistic concepts refer thus to the value of tradition expressed by a reasonable hierarchy of possibilities that is linked to the context, which may differ in different cultures. Differences in the values are also reflected in the concept of the good lives (Sisáková 2001, 203-204).

According to Ricoeur (1993) the essence of humanity resides in producing meaning, which is linked to human identity; human identity relies on the differences in the personalities of others as well as on the continuity of the personality that implies the duration of personality traits independent of time and life circumstances. The realization of the desire to lead the good life lies in the ability to find meaning and satisfaction in self-realization. The Canadian moral philosopher C. Taylor (2001) writes that human life is structured by that to which we attribute meaning; it is therefore impossible to act beyond these value frameworks. In the culture of today, however, all the values that created the "backdrop" for the whole of society and that legitimized our life strategies have been debased. There are also other authors who draw attention to the

1 Logotherapists think that well-being is not necessarily a sufficient indicator of satisfaction with life. We all wish to be happy but well-being is not the decisive factor in our lives (Lukasova 1997, 25-26). 
fact that people in contemporary western civilization are exposed to the pressure of current culture that brings about problems following on from the incompatibility of the value systems embodied in this culture. Maslow (2000) wrote that from the perspective of history, we are in a value interregnum where all external value systems (political, economic, religious, etc.) have been shown to be flawed. He emphasized the necessity for a valid system of values that people could believe in. Many disorders in children and adolescents can be understood, according to Maslow, as a result of the adults' uncertainty in the domain of values. Therefore, many young people do not live by adult values, but by immature values, which are simplistic and determined to a great extent by adolescent needs.

Without attributing the central role in human life to instincts, passions or the principles of pleasure, humanistic psychologists believe in the possibility of living the good life and not only on the basis of rationality. Rogers believes that people have to seek the essence of values in their inner lives rather than outside; this is why human beings themselves have innumerable resources for building the good life. People should look to themselves to find what they feel is valuable rather than looking to what is said to them that is worthwhile. They should search for the resources of the good life in themselves, not in an outward dogma, sentence or material form (Rogers 1997).

\section{Integrity}

Humanistic psychologists are also convinced that people should try to achieve integrity for the sake of the good life; it presupposes the integrity of the self and is bound up with the perception of our life as a whole. According to Rogers, those people live up to their values (they reject hypocritical culture and do not lead double lives) although they realize that they are in a permanent process of change and are prepared for that. A psychologically mature person aims to have an integrated encounter with life and its challenges, moving towards completeness, integrity and unity (ibid.). ${ }^{2}$ Rogers is convinced that developing the capacities and opportunities in humans leads to growth, maturity and the enrichment of life and represents a constant developmental motivation manifested as an increase in autonomy, integrity and responsibility (Rogers 1999).

A movement towards unity and integration in humanistic psychology is taking place, focusing on human nature, which has a tendency to persist although the culture itself may progress in the opposite direction when attempts are made to suppress it. If this inner core of human nature is frustrated, denied or suppressed, Maslow's character disorder comes into play, which can be manifested by the loss of any substantial characteristic of humanity, the rejection of values, etc. Frustration of basic needs is not the only source of disease or human atrophy (Maslow 2000). Maslow wrote that dichotomic thinking is regarded as immature in psychiatry, it often points to a lower level of personality development in mental functioning. Healthy people tend to integrate Freudian dichotomies and trichotomies; instincts and defenses do not exist in opposition in healthy people but are integrated and from the perspective that conative, cognitive, affective and motor aspects cooperate together without conflict and pursue the same aims. The integration of rational and irrational strengths (conscious and unconscious, primary and secondary processes) is equally important. ${ }^{3}$ Integration also takes place at the level of understanding one's life as a whole since both the past and the future exist in the individual

2 People living the good life are characterized by their struggle to achieve integrity of life where ideas, feelings, physical and mental energies are all integrated in living. 
now. The point at issue is thus not only the past (as Freud had already shown) but also the future which in humans comes in the form of ideals, hopes, duties, tasks, plans, objectives, missions, etc. People who do not see that it is their future that organizes their activities are reduced to facts and emptiness (Maslow 2000).

MacIntyre (2004) underscores that a precondition for being able to lead the good life and perceive it as meaningful is the ability to plan and deal with long-term projects. However, each daily attempt to perceive human life as a whole, as a unity, is faced with two kinds of problems-social and philosophical. The social problem is that the modern age divides every human life into a number of segments with its own norms and own ways of behaviour: work is thus separated from relaxation, private life from public life, social life from private life, childhood and old age are separated from the rest of life. All these separations are so deeply ingrained that we learn to think and feel according to the differences of each individual part of life, and not from the perspective of the unity that passes through these stages in life. The philosophical problem follows on from the tendency towards an atomistic reflection of human behaviour, on the basis of which it seems impossible to understand how life can be something more than a mere sequence of isolated and unrelated episodes. This also springs from the isolation of the individual from his or her particular roles in life and the liquidation of the self plays a part in it due to the reduction of his or her identity (ibid.). In contrast, MacIntyre accentuates the fact that an individual is the subject of a story lasting from birth to death and that means that people bear responsibility for their behaviour and the events of their lives. People have to be ready to give an explanation of what they have done, of what has happened to them. The unity of the individual life is the unity of the story embodied in that individual life, a unity of the narrative search, which is at the same time self-knowledge (ibid., 253-255). Moreover, MacIntyre regards integrity not only as a precondition for the good life but he also draws attention to the tradition of it being understood as a virtue, which, in relation to the whole of human life is defined by the virtue of integrity or stability (ibid., 237). This virtue has today receded with regard to the powerful ideal of flexibility that is making inroads into all areas of life in western culture. The retreat of this virtue is also observable in our milieu.

\section{Creativity and Authenticity}

The second half of the last century witnessed the gradual entry of the issues of "authenticity" and "creativity" into the humanities (chiefly psychology, philosophy, and sociology). This was also reflected in perceptions of the ideal life. Postmodern thought rejected narration as the embodiment of non-authenticity since each story assumes that there is a certain kind of order in the phenomenon to be described; the good life can then be linked to irreducible openness, unlimited experimentation or simply drifting along. The accentuation of "creativity" is reflected in the aesthetization of the ethical (which, in practice means replacing the ethical aspect with the aesthetic one). For instance, M. Foucault continues Nietzsche's line of thought

\footnotetext{
3 Rogers $(1995,154)$ sees one of the most important attributes of the good life in an individual's 'openness to experience'; where people become more capable of listening to themselves, of feeling what is happening inside them; they are more open to the feelings of fear, disgust, pain, courage, love and respect. They are able to live experiences fully and do not dispel them from consciousness. People who trust their experiences are able to select the most satisfying behaviour from many possibilities. This trust is not based on being infallible but on peoples' ability to be fully open to the consequences of their deeds and the opportunity to repair them if they are shown to be unsatisfactory.
} 
and in Rorty the good life fuses with artistic uniqueness; Rorty underscores the originality of the approach to life and its incompatibility with its resemblance to others. ${ }^{4}$ Postmodern thought thus takes the trend of the aesthetization of the ethical to the extreme, where the aesthetical becomes a constitutive dimension (for more details see, Šulavíková 2005; Šulavíková 2006b). However, the demand for authenticity and creativity with regard to human life does not have to remain in this radical position, as evidenced by the approaches of humanistic psychologists or the concepts of C. Taylor and others. ${ }^{5}$

For example, C. R. Rogers understands authenticity to be a pre-requisite for the good life not only at the level of envisioning and living one's life, which can lead to the overvaluation of the individual's personality traits, but for that person authenticity is also something that enhances the quality of the connection to others. Although, as other postmodern authors have suggested, the individual's desire for self-development, for absorbing ever more opportunities and for continued learning, engenders permanent change and is the basis of the good life. Authenticity represents not only a necessary precondition for mental health but it is also an ethical demand that contributes to the quality of human relations. The demand for creativity manifests itself within a much broader area than that found in Rorty for example: it confers a better quality to both the private sphere (in terms of individual and family life, where both conformity and stereotypes must be overcome, in terms of way of life, where creativity may help in overcoming passivity) and the social sphere. Rogers links the particular social need for creative behaviour with education where it can be helpful in overcoming stereotypes and conformism, with the sphere of science where it is necessary in improving technological procedures, with industry, where creativity should be introduced into labour; he also sees it as necessary in enhancing the quality of social institutions. C. Taylor links authenticity and the ethical aspect more closely. He is convinced that human dignity is found mainly in autonomy - the ability of every human being to create their own ideas of the good life without being controlled by anyone else. Since he believes that personal identity can be constituted only against a background of the 'horizon of senses' and 'the things that matter', authenticity is not the adversary of the demands put on an individual but, on the contrary, it presupposes them. He thinks it is necessary to overcome the atomistic individualism wide-spread throughout contemporary culture that stems from the loss of the sense of a wider social horizon of individuals' activities. It is desirable to legitimize demands originating from beyond our desires and aspirations (Taylor 1992). For these authors, authenticity (see Šulavíková 2007) based on creativity is a precondition for a better social life. The good life is then not only linked with the aesthetic experiences that emanate from a person's uniqueness but also with experiencing truth, the ethical and social values of life.

\footnotetext{
4 Rorty (1996) is known for his postmodern view of self-creation through ever new alternative narrations and alternative vocabularies as tools for self-improvement, self-creation, self-development. Exceptional people are able to produce significantly original self-creations, to make works of art of their lives. Original and innovative life is according to him the result of adventurous quest and selfenrichment.

5 All of them regard authenticity as one of the most important attributes of the good life. It is characterized by its rejection of hypocrisy, deception, two-facedness but also by its quest for values that transcend the individual. C.R. Rogers also states $(1995,161)$ that the process of the good life is one of permanent development, of implementing more and more of one's possibilities, of learning how to understand them. Freedom is autonomous decision-taking and a creative approach to one's relationships to the environment; Rogers' attitude does not show, however, why the freedom to be oneself should necessarily be incompatible with resemblance to others.
} 
In the history of philosophy creativity was understood to be closely associated with the perception of freedom. From ancient times creativity had chiefly been connected with the domains of art and science and only later did it become part of everyday life. In the nineteenth century J. S. Mill formulated his views on this issue in which he linked creativity with originality and the genius of extraordinary, strong individualities. Mill argues that geniuses are greater individualities than other people, less able to squeeze into the narrow framework society provides to protect its members from the difficulties associated with the shaping of their character (Mill 1972). The concept of creativity soon extricated itself from the sphere of exclusivity; behaviourism, for instance, is now concerned with "creative behaviour" in the private and public spheres. From as early as the period of the Enlightenment, the concept of originality has also sought to free itself from the shadow of exclusiveness because it is connected with human nature itself; it is reflected in the demand to live one's own life in harmony with one's self, with one's originality. This approach to originality, which is naturally interlinked with creativity in relation to building one's own life becomes the basis for understanding authenticity as a psychological need and ethical challenge: these ideas have been regarded as significant from the second half of the twentieth century onwards in philosophy, psychology, ethics and the social sciences as a whole. A. H. Maslow points out that the term creative is used not only as an attribute of products but also as a personality trait concerning people and their activities, processes and attitudes. It does not only relate to standard and conventionally accepted artifacts, such as poems, theories, novels, experiments or paintings. In this respect he remarked wittily that in his opinion a first-class soup is more creative than a second-rate painting (Maslow 2000, 144). Creativeness, as he understands it, places emphasis primarily on the personality and not on the person's performance, which is a secondary manifestation of personality. This creativity consists of personality qualities such as straightforwardness, courage, freedom, spontaneity, integration, self-acceptance; creativity intervenes throughout life regardless of problems. Maslow denotes this creativeness as the defining characteristic of the essence of humanity (ibid.). ${ }^{6}$ Creativeness therefore becomes a potential characteristic of all people and can be reflected in all spheres of life; of course, it is closely connected with the precondition for the possibility of free development and manifestation, with the possibility of authentic manifestation.

\section{Community}

The overvaluation of the aesthetic side of life and its understanding as a work of art in postmodern thought is based not only on the uncontrolled accentuation of individual creativity in relation to one's life but also on an overrating of the "authorship" of the self in terms of constituting the self to the detriment of the social interaction component. It is not possible to take life out of the web of relations in which it is integrated.

C. R. Rogers' conception of the good life is congruous in many ways with the ideas of Kierkegaard and M. Buber: he argues that the feelings experienced in the good life are deeper. An individual feels that he or she is more unique and more real, that his or her relationships lose superficiality, become deeper, more satisfying and attract more from the reality of other human

\footnotetext{
6 According to Maslow (2000) creativeness is 'a fundamental characteristic of common human nature'. It is clear to Rogers (1995) that individuals living the good life are creative: their sensitive openness to their world, their trust in their own abilities to establish new relationships to the environment, make them the types of humans living creative lives.
} 
beings (Rogers 1999). ${ }^{7}$ Rogers' ideal of the good life is thus directly linked with the ability to deepen human relationships.

To a large extent, people weave their ideas of the good life out of the relationships they have with other people. These connections between people are usually based on relationships of love, and for those people who have been shaped by the values of our environment, love is naturally based on the possibility and ability not only "to accept" but also "to give". Humanistic psychologists as critics of the psychoanalytical theory of motivation emphasize this moment in their writings about love for the sake of the existence of another human being, about unselfish love, and not only selfish love. Love as one of the basic human needs is founded on the dimension of "giving" and "accepting" as it is characteristic of humans that just as they accept external stimuli they also transmit them. The necessity of bilateral causal interaction with the environment assumes that it is possible to develop both egoistic and altruistic elements in the human mind. Present-day cultural anthropology assumes that the human race would not have been able to survive (e.g. in the Ice Age) if the human mind had not been capable of the unselfish perception of reality and behaviour based on altruistic elements or principles. At the same time we should also mention a tendency in the contemporary meritocratic world as described by Z. Bauman. Bauman argues that successful people do not need community in the same way as individuals who are unable to apply their individuality; the latter existing de jure but not de facto. Successful people have the potential to gain little from the web of community commitments and they may lose everything if they become trapped in it. On the other hand, the desire for freedom and a sense of community can arouse controversy. The lack of one of these does not contribute to life satisfaction (Bauman 1995).

\section{Conclusion}

For Plato the good life has to be controlled by reason. However, it is accessible only to philosophers because they love eternal truth, whereas ordinary people love seeing art and practical life. According to Aristotle intellectual activity and citizens' participation in political life are most important for the good life. The good life covers theory (representing contemplative perception of the cosmic order) and the activities of individuals as citizens of the state. In both these ancient concepts the good life is grounded on special activities of higher actions that represented a higher form of human existence. Perception of the good life has gradually been transferred to the region of everyday life - a characteristic of modern identity today, according to Taylor. The core of the good life lies now in something in which anybody can participate and not only in the areas that were previously accessible to rich people. He underscores that from the Enlightenment onwards, a particular inner value has been anchored in natural life, the task of finding positive justification for our lives and we ourselves have to find the source of inner value (Taylor 1992, 96). Today, people find themselves confronted by a potential trap, in the form of a strong, double-pronged media-promoted ideal. The first is the idea of an adventurous life with non-traditional experiences which should be sought after and "enjoyed" as would be an exclusive box of chocolates; the second is a life focused on the world of success, on finding

7 In his explanation he refers to Buber: in these relationships an individual affirms another one (accepting all of his or her potentiality, recognizing the human being in him or her who was created to develop and be developed), accepts it as a process of being; a relationship has to be understood as an opportunity "to strengthen" all that humans are, with all their possibilities and abilities: Buber then affirms the individual as a living human being capable of creative inner development (Rogers 1995). 
a place in the world of wealth and status. Freedom in both of these is highly problematic: people do not necessarily succeed in escaping from the stream of clip-on prospects that they seek to take at all cost. So they use their abilities to join the never-ending whirl of activities and struggles, where there is no more space for becoming aware of and perceiving a deeper meaning and for formulating their specific ideal of the good life. ${ }^{8}$

\section{References}

Bauman, Z. Úvahy o postmodernej dobe. Praha: Sociologické nakladatelství, 1995.

Buraj, I. Moc nad telom a jej súčasné podoby. In Filozofia a život - život filozofie. Bratislava: Iris, 2004.

Foucault, M. Návrat morálky. In Za zrkadlom moderny. Bratislava: Archa, 1991.

Hnilica, K. Vlivy materialistické hodnotové orientace na spokojenost se životem. Československá psychologie, XLIX, 5, 385-398, 2005,

Lipovetsky, G. Soumrak povinnosti. Praha: Prostor, 1999.

Lipovetsky, G. Třetí žena. Neměnnost a proměny ženství. Praha: Prostor, 2000.

Lukasová, E. Logoterapie ve výchově. Praha: Portál, 1997.

Macek, P. Adolescence. Psychologické a sociální charakteristiky dospívajících. Praha: Portál, 1999.

MacIntyre, A. Ztráta cnosti. Praha: Oikoymenh, 2004.

MacIntyre, A. Transformácia liberalizmu na tradíciu. In O slobode a spravodlivosti. Bratislava: Archa, 1993.

Maslow, A., H. Ku psychológii bytia. Modra: Persona, 2000.

Mill, J. S. O slobode. Bratislava: Pravda, 1972.

Ricoeur, P. Já hodné uznání a úcty. Filosofický časopis, 61, 1, 1993.

Ricouer, P. Život, pravda, symbol. Praha: Oikoymenh, 1993.

Rogers, C. R. Spôsob bytia. Modra: IRO, 1997.

Rogers, C. R. O osobnej moci. Modra: IRO, 1999.

Rogers, C. R. Ako byt sám sebou. Bratislava: Iris, 1995.

Rorty, R. Nahodilost, ironie, solidarita. Praha: UK, 1996.

Shusterman, R. Estetika pragmatizmu. Krása a umenie života. Bratislava: Kalligram, 2003.

Sisáková, O. Filozofia hodnôt medzi modernou a postmodernou. Prešov: FF PU, 2001.

Šulavíková, B. "Etické", "estetické” a dobrý život. Filozofia 60, 4, 230-241, 2005.

Šulavíková, B. Ideál flexibility a paradoxy kultu mladosti. Filozofia 61, 6, 441-452, 2006 a.

Šulavíková, B. Autenticita a dobrý život. Bratislava: Album, 2006b.

Šulavíková, B. Autenticita a kult individuality. Československá psychologie 51, 80-90, 2007.

Taylor, C. Etika autenticity. Praha: ČSAV, 2001.

Taylor, C. Humanizmus a moderní identita. In Člověk v moderních vědách. Praha: ČSAV, 1992.

Department of Social and Biological Communication

Slovak Academy of Sciences

Klemensova 19

81364 Bratislava

Slovak Republic

Tel.: 00421-2-54775683

E-mail: ksbkblan@savba.sk

8 This work has been sponsored by VEGA grant No. 2/6043/26 and COPART SAS. 